\title{
ఇUSGS
}

\section{Volcano Hazards at Newberry Volcano, Oregon}

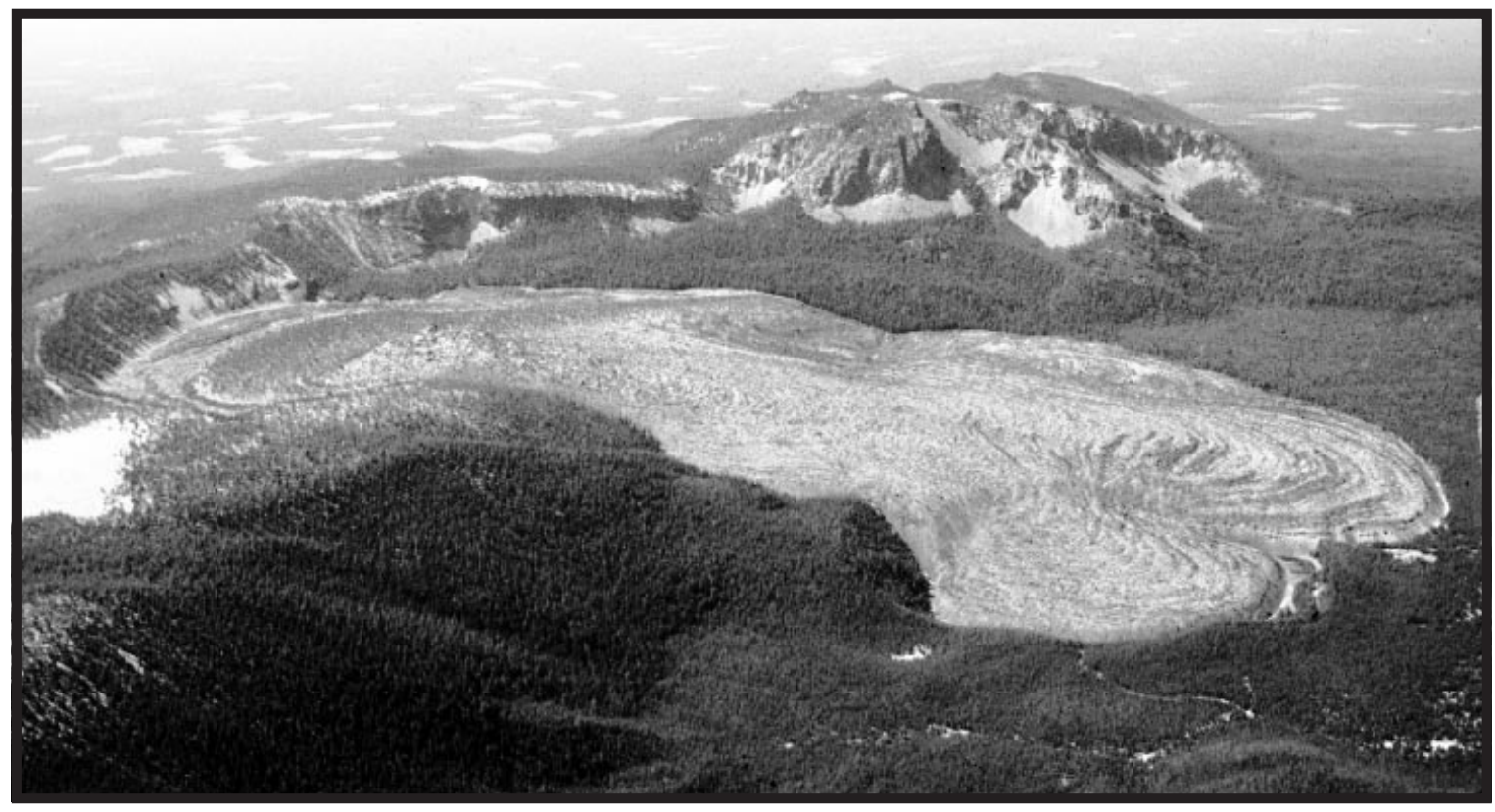

By

David R. Sherrod ${ }^{1}$, Larry G. Mastin ${ }^{2}$, William E. Scott ${ }^{2}$, and Steven P. Schilling ${ }^{2}$

${ }^{1}$ U.S. Geological Survey, Hawaii National Park, HI 96718

${ }^{2}$ U.S. Geological Survey, Vancouver, WA 98661

\section{OPEN-FILE REPORT 97-513}

This report is preliminary and has not been reviewed for conformity with U.S. Geological Survey editorial standards or with the North American Stratigraphic Code. Any use of trade, firm, or product names is for descriptive purposes only and does not imply endorsement by the U.S. Government. 


\section{CONTENTS}

Introduction $\quad 1$

Hazardous volcanic phenomena 2

Newberry's volcanic history is a guide to future eruptions 2

Flank eruptions would most likely be basaltic 3

The caldera would be the site of most rhyolitic eruptions - and other types of dangerously explosive eruptions 3

The presence of lakes may add to the danger of eruptions in the caldera 5

The most damaging lahars and floods at Newberry volcano would be limited to the Paulina Creek area 5

Small to moderate-size earthquakes are commonly associated with volcanic $\begin{array}{ll}\text { activity } & 6\end{array}$

$\begin{array}{ll}\text { Volcano hazard zonation } & 7\end{array}$

Hazard zone for pyroclastic eruptions $\quad 7$

$\begin{array}{ll}\text { Regional tephra hazards } & 8\end{array}$

Hazard zone for lahars or floods on Paulina Creek $\quad 8$

Hazard zone for volcanic gases $\quad 10$

Hazard zones for lava flows $\quad 10$

Large-magnitude explosive eruptions of low probability 11

Monitoring and warnings 12

Suggestions for further reading $\quad 12$

$\begin{array}{ll}\text { Endnotes } & 13\end{array}$

\section{ILLUSTRATIONS}

Plate 1. Volcano hazards at Newberry volcano, Oregon

in pocket

Figure 1. Index map showing Newberry volcano and vicinity

Figure 2. Notable volcanic events at Newberry volcano and in central

Oregon during the past 15,000 years 2

Figure 3. Characteristic volcanic phenomena expected for eruption of small to moderate volumes of rhyolite

Figure 4. Map showing annual probability of $1 \mathrm{~cm}$ or more of tephra accumulation

Additional paper copies of this report can be purchased from the U.S. Geological Survey, Information Services, Box 25286, Federal Center, Denver, CO 80225

Cover photo: Big Obsidian Flow (center), a 1,300-year-old lava flow, is the youngest product of Newberry volcano. Paulina Peak (back center) forms the highest point on the rim of Newberry Crater, a large caldera or volcanic depression at the summit of the volcano. 


\section{INTRODUCTION}

Newberry volcano is a broad shield volcano located in central Oregon (fig. 1). It has been built by thousands of eruptions, beginning about 600,000 years ago. At least 25 vents on the flanks and summit have been active during several eruptive episodes of the past 10,000 years. The most recent eruption 1,300 years ago produced the Big Obsidian Flow. Thus, the volcano's long history and recent activity indicate that Newberry will erupt in the future.

The most-visited part of the volcano is Newberry Crater, a volcanic depression or caldera at the summit of the volcano. Seven campgrounds, two resorts, six summer homes, and two major lakes (East and Paulina Lakes) are nestled in the caldera. The caldera has been the focus of Newberry's volcanic activity for at least the past 10,000 years. Other eruptions during this time have occurred along a rift zone on the volcano's northwest flank and, to a lesser extent, the south flank.

Many striking volcanic features lie in Newberry National Volcanic Monument, which is managed by the U.S. Forest Service. The monument includes the caldera and extends along the northwest rift zone to the Deschutes

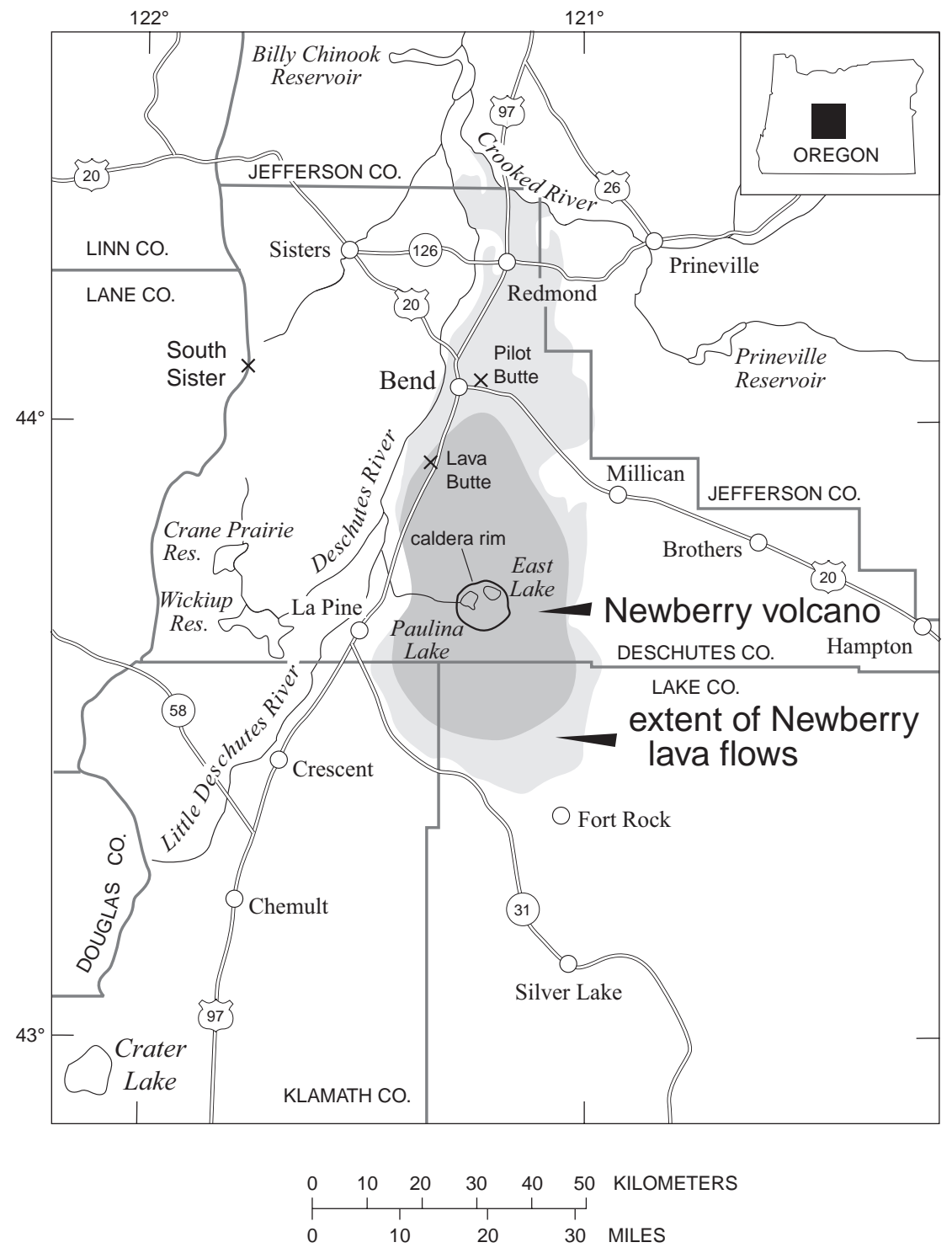

Figure 1. Index map showing Newberry volcano and vicinity. 
River. About 30 percent of the area within the monument is covered by volcanic products erupted during the past 10,000 years from Newberry volcano.

Newberry volcano is presently quiet. Local earthquake activity (seismicity) has been trifling throughout historic time. Subterranean heat is still present, as indicated by hot springs in the caldera and high temperatures encountered during exploratory drilling for geothermal energy.

This report describes the kinds of hazardous geologic events that might occur in the future at Newberry volcano. A hazard-zonation map is included to show the areas that will most likely be affected by renewed eruptions. In terms of our own lifetimes, volcanic events at Newberry are not of day-to-day concern because they occur so infrequently; however, the consequences of some types of eruptions can be severe. When Newberry volcano becomes restless, be it tomorrow or many years from now, the eruptive scenarios described herein can inform planners, emergency response personnel, and citizens about the kinds and sizes of events to expect.

\section{HAZARDOUS VOLCANIC PHENOMENA}

\section{Newberry's volcanic history is a guide to future eruptions}

Future eruptions at Newberry volcano will probably resemble those that occurred in the past 15,000 years (fig. 2). These volcanic eruptions varied widely from relatively quiet

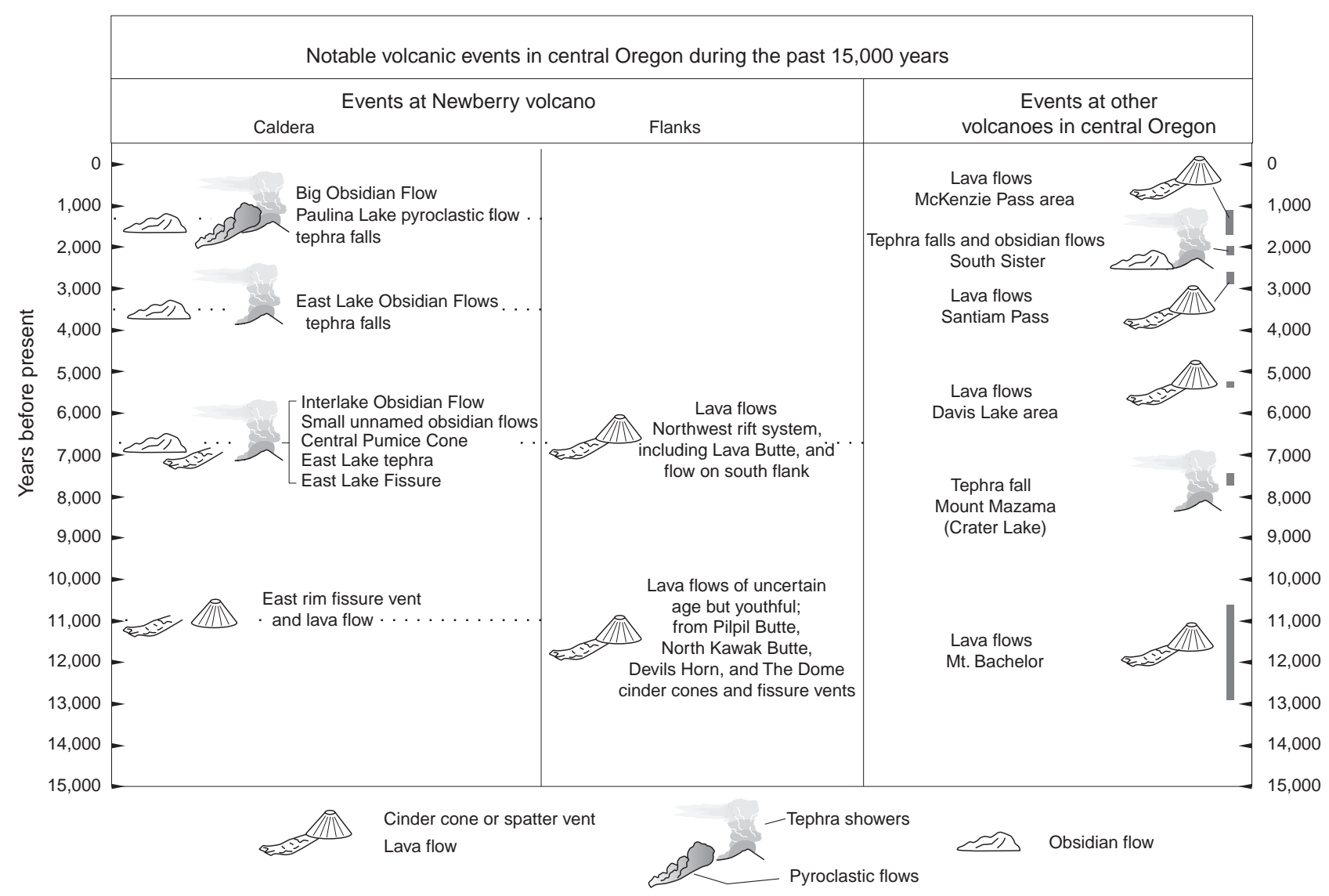

Figure 2. Notable volcanic events at Newberry volcano and in central Oregon during the past 15,000 years. Dotted lines show approximate age of events at Newberry volcano; shaded boxes show age of events at other volcanoes. No eruptions have occurred in the past 1,000 years in this region. 
effusion of lava flows to highly explosive discharge of pumice and ash. The difference in eruptive style stems from the composition of the magma, or molten rock, and the amount of dissolved gas it contains. At Newberry volcano, the most common magma types are basalt and rhyolite, and each has characteristic eruptive phenomena associated with it.

\section{Flank eruptions would most likely be basaltic}

Basaltic eruptions are well known from observations elsewhere, such as at Hawaii, where spectacular fountains of spatter and cinders are associated with lava flows. At Newberry, basaltic eruptions have occurred repeatedly on the volcano's flanks and in the caldera. Typical products of a basaltic eruption are the 7,000-yr-old cinder cone of Lava Butte and its surrounding lava flows, located $10 \mathrm{~km}(6$ mi) south of Bend (fig. 1). Basaltic eruptions commonly begin with lava fountains that hurl cinders or spatter as far as $1 \mathrm{~km}(0.6 \mathrm{mi})$ from the vent. Ejecta are thrown aloft for hundreds to a few thousand meters. Large fragments are expelled from the vent along ballistic trajectories, like artillery shells. Smaller particles are carried by wind and convective updrafts. The resulting deposits may be many meters thick near the vent and build a steepsided cinder cone, but they generally thin to a few millimeters within $10 \mathrm{~km}(6 \mathrm{mi})$ distance downwind. The chief hazard from ballistic ejection is direct impact. Some spatter will be hot upon impact and likely will start forest fires.

Lava flows may also issue from cinder cones or drain away from spatter ramparts that are built by lava fountains. Lava flows are streams of molten rock that move downslope until they cool and solidify. People and animals can walk or run from lava flows, which on average move less than about $500 \mathrm{~m}$ per hour (30 ft per minute). But any structures in the flow path are burned or crushed.

Basaltic magma may erupt from long linear fissures or from pipe-like vents. Excellent examples of both are found along Newberry's northwest rift system, which formed about 7,000 years ago. The northwest rift system traverses the volcano's northern flank for $22 \mathrm{~km}$ (14 mi) from Lava Butte to the caldera. East Lake Fissure, on the caldera wall north of East Lake, marks the southern extent of the northwest rift system. The rift system includes 12 lava flows that range from 1 to $9 \mathrm{~km}$ in length ( 0.6 to $5.6 \mathrm{mi})$ and cover areas as great as $24 \mathrm{~km}^{2}$ $(6,000$ acres or 9 square miles). In total, lava flows of this eruptive episode covered more than $60 \mathrm{~km}^{2}$ (23 square miles).

\section{The caldera would be the site of most rhyolitic eruptions-and other types of dangerously explosive eruptions}

Rhyolitic eruptions have been restricted to the caldera during the past 10,000 years. Rhyolitic magma tends to erupt more explosively than basaltic magma, owing to the increased amount of gas commonly trapped in it. Gas bubbles in rhyolite cannot easily rise and escape as they can from basalt, and gas pressures may build to much higher levels. This is because rhyolite is more viscous (resistant to flowage) than basalt. Gas-rich eruptions are generally more explosive and therefore more dangerous than gas-poor eruptions. Some events expected in a rhyolitic eruption are shown in figure 3.

Explosive volcanic eruptions discharge debris that is highly fragmented, mainly as a consequence of gases that froth and disrupt the magma as they expand. Geologists use the term "pyroclastic" (literally, fire-broken) to describe these explosive eruptions and the resulting deposits. Pyroclastic eruptions present the greatest threat to lives because of their violence and the great speed with which the material can sweep out from vents.

During rhyolitic eruptions, gas-charged magma and rock along the sides of vents are broken into fragments, called tephra, that range in size from large blocks to fine dust. The tephra is jetted into the atmosphere to form clouds that rise and drift downwind. Larger particles fall close to the vent, but finer-grained tephra can be carried for tens to hundreds of kilometers. Tephra clouds can create darkness lasting tens 

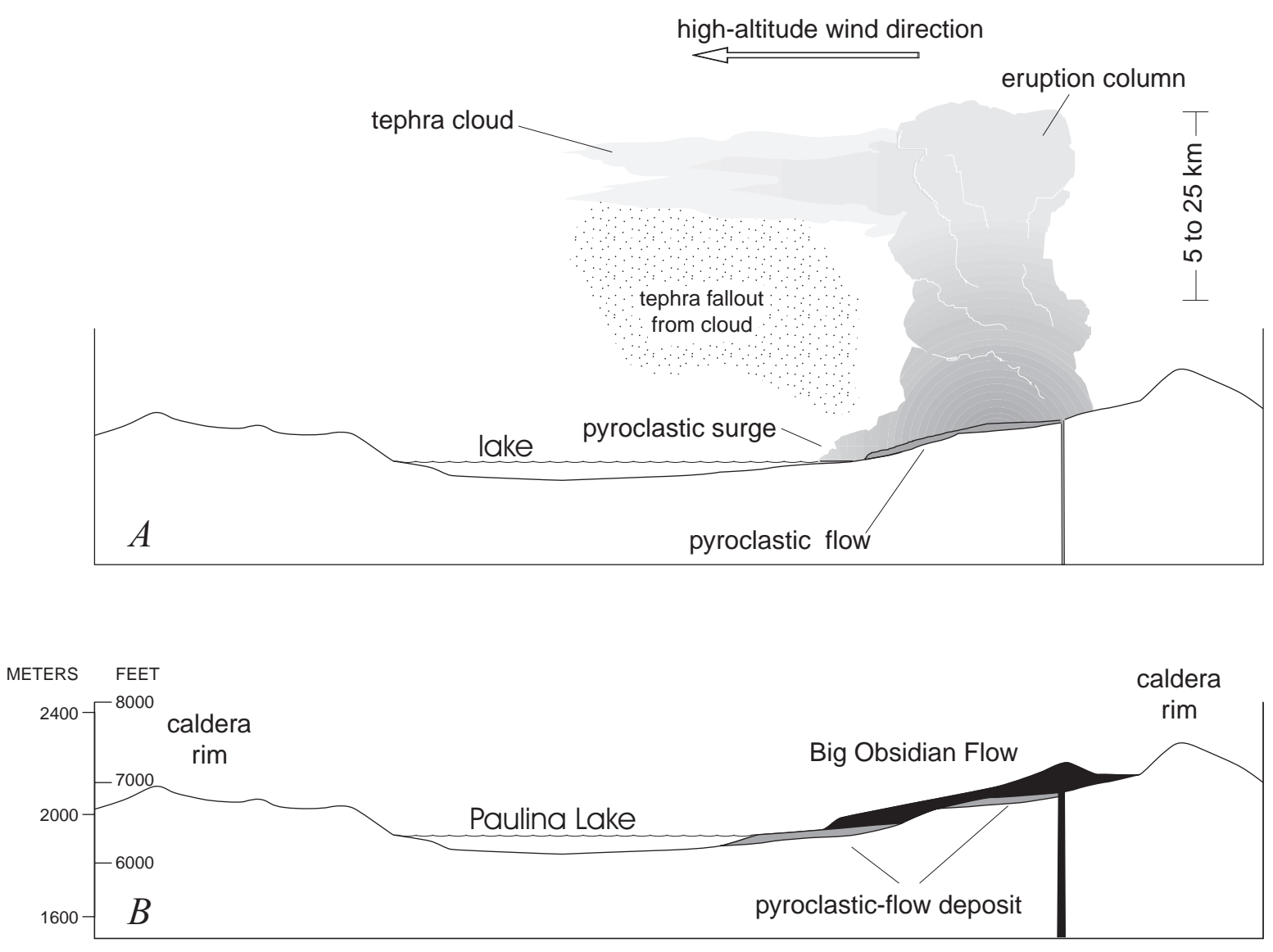

VERTICAL EXAGGERATION X2

Figure 3. Characteristic volcanic phenomena expected for eruption of small to moderate volumes of rhyolite at Newberry caldera. $A$, eruptive process. Not shown is a final oozing of degassed magma to form obsidian flow. $B$, setting today after such a sequence of events 1,300 years ago. During that particular eruption, prevailing winds forced the tephra cloud eastward to blanket the east flank of volcano with thick fall deposit.

of minutes to hours, even on sunny days. Deposits of tephra can short-circuit electric transformers and power lines, especially if the tephra is wet, which makes it highly conductive, cohesive, and heavy. Tephra ingested by engines will clog filters and increase wear. Tephra clouds often generate lightning that may interfere with electrical and communications systems and start fires. Perhaps most importantly, even dilute tephra clouds pose a substantial hazard to aircraft that fly into them.

In contrast to tephra clouds that ascend into the atmosphere, other mixtures are denser than air and flow along the ground surface, driven by gravity. These mixtures, known as pyroclastic flows, are hot-from 300 to more than $800^{\circ} \mathrm{C}\left(570\right.$ to $\left.>1,470^{\circ} \mathrm{F}\right)$. They descend a volcano's flanks at speeds ranging from 10 to more than $100 \mathrm{~m}$ per second (20 to $>200 \mathrm{mi}$ per hour). Described figuratively as "glowing avalanches," these mixtures are sufficiently dense to be funneled into canyons or other topographically low areas.

If the hot mixture is composed mostly of gas with a small proportion of rock and ash, its lower density makes its path less governed by topography. Flows of this type are called pyroclastic surges. Pyroclastic flows and 
surges often occur together. They can incinerate, asphyxiate, bury, and crush objects and living things in their path. Because of their high speed, pyroclastic flows and surges are difficult or impossible to escape. Evacuation must take place before such events occur.

Lava flows may also form during rhyolitic eruptions. Rhyolitic lava is so viscous that it typically solidifies without much crystallization, forming volcanic glass called obsidian. Rhyolitic lava may squeeze from the vent to form a steep-sided lava dome. Lava domes and thick lava flows move only meters per day and are not especially hazardous. But the steepened faces may collapse without warning, spawning avalanches of hot volcanic debris that can generate destructive pyroclastic flows and localized clouds of airborne tephra.

The eruptive sequence that culminated in the Big Obsidian Flow 1,300 years ago exemplifies several aspects of a typical rhyolitic eruptive sequence at Newberry volcano. The eruptions began with tephra showers that deposited pumice lumps and dense lava blocks

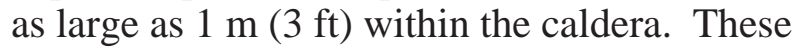
tephra deposits, which are thicker than $13 \mathrm{~m}$ (43 $\mathrm{ft}$ ) near the vent, diminish in thickness and grain size downwind. For example, $50 \mathrm{~km}$ (30 mi) downwind from the caldera near Brothers, Oregon, these tephra deposits are $25 \mathrm{~cm}(1 \mathrm{ft})$ thick and have average grain size of $3 \mathrm{~mm}(0.1$ in.). Newberry tephra can be traced as a finegrained ash deposit as far east as Idaho.

As the eruption progressed, pyroclastic flows swept downslope from the Big Obsidian vent to Paulina Lake (fig. $3 A$ ). The boat ramp at Little Crater Campground is excavated in these pyroclastic-flow deposits, as is the caldera road upslope from Paulina Lake. The flows entered Paulina Lake, perhaps causing secondary steam explosions and displacing water from the lake into Paulina Creek.

The final stage of eruption produced the Big Obsidian Flow itself, a lava flow that moved slowly, probably advancing only a few meters or tens of meters per day as it oozed down an inner caldera wall and ponded on the caldera floor (fig. 3B). The Big Obsidian Flow is about $1.8 \mathrm{~km}(6,000 \mathrm{ft})$ long and locally thicker than $20 \mathrm{~m}(65 \mathrm{ft})$.

\section{The presence of lakes may add to the danger of eruptions in the caldera}

The mixing of magma, either basaltic or rhyolitic, with water tends to change the character of the eruption from one of continuous expulsion of lava or tephra to one involving discrete explosions. The major hazard produced during such explosions is pyroclastic surges of tephra, gas, and steam that radiate out from the vent at speeds as great as hundreds of kilometers per hour and temperatures that range from $100^{\circ} \mathrm{C}\left(212^{\circ} \mathrm{F}\right)$ to several hundred degrees Celsius. Such surges typically extend less than $1 \mathrm{~km}$ from an eruptive vent, but some may reach as far as $10 \mathrm{~km}(6 \mathrm{mi})$.

\section{The most damaging lahars and floods at Newberry volcano would be limited to the Paulina Creek area}

Lahars are watery flows of volcanic rocks and mud that surge downstream like rapidly flowing, soupy concrete. Lahars, also known as mudflows or debris flows, can devastate valley floors tens of kilometers from the volcano. Lahars are a major hazard at steep-sided, snowand ice-clad Cascade volcanoes, but they pose much less of a threat at Newberry volcano. The volcano's slopes are relatively gentle, and although it commonly bears a thick seasonal snowpack, it has no glaciers. Pyroclastic flows and surges that encounter a snowpack on the outer upper flanks may generate lahars and floods in some of the numerous small valleys that crease the volcano's flanks, especially the northeast flank. Such lahars and floods will spread out and attenuate on the lower flanks or in basins beyond the volcano, such as Millican Valley.

The valley of Paulina Creek, which drains from Paulina Lake through the west rim of Newberry Crater, is the most likely drainage to carry damaging lahars and floods. In addition to lahars and floods caused by pyroclastic flows melting snow, a lahar could be generated along Paulina Creek by lake overflow. The natural bedrock barrier that forms the spillway from the lake is stable and unlikely to fail 
catastrophically, but pyroclastic flows entering the lake or explosive eruptions in the lake could displace water into Paulina Creek's canyon. A large water flow could incorporate enough debris from the canyon walls to become a lahar or it could remain as sediment-laden floodwater.

Geologic evidence suggests at least one such flood occurred in the recent geologic past, but its exact origin is uncertain. It may have been triggered by failure of a 1.5-m-high (5-ft-high) rock ledge at the outlet rather than by an eruption $[\mathrm{A}]$. The flood inundated the entire valley floor in the reach above Paulina Prairie and probably had a discharge similar to that of the flood of record (in 1909) on the Deschutes River downstream from its confluence with the Little Deschutes River (which receives Paulina Creek flow). On the basis of published reports from other volcanoes around the world, similar or larger floods could accompany future eruptive activity in Paulina Lake. ${ }^{[B]}$

Lahars travel faster than water in channels of similar depth and slope. And because they carry mostly solid debris, lahars are more destructive. They destroy bridges, break and fill pipelines, and clog ponds and reservoirs. They can also bury roadways, houses, and extensive areas of agricultural, forest, or grazing land. Lahars or floods from Paulina Lake could reach the La Pine valley within 30 minutes, so areas likely to be impacted should be evacuated before an eruption occurs. High ground near these areas, such as tops of ridges or buttes, is likely to be safe and may provide suitable emergency refuge.

\section{Small to moderate-size earthquakes are commonly associated with volcanic activity}

Earthquakes occur when rocks break suddenly in response to various geologic forces. Magma moving in the Earth's crust may create sufficient force to produce volcanic earthquakes. More common, however, are tectonic earthquakes, which periodically strike parts of Oregon. These earthquakes, the result of fault movements driven by regional crustal stresses, typically have no direct connection to magma movement. Regardless of type, earthquake size is reported by magnitude, and many scientists and media describe earthquakes by the well-known Richter magnitude scale.

Volcanic earthquakes are commonly smaller than about magnitude 2.5 , roughly the threshold for felt shaking by observers close to the event. Swarms of small earthquakes may persist for weeks to months before eruptions, but little or no damage would occur to buildings in surrounding communities. Some volcanicrelated swarms may include earthquakes as large as about magnitude 5. For the communities of Bend, La Pine, and Sunriver, shallow earthquakes in the magnitude 4-5 range that are located beneath Newberry volcano would cause walls to rattle or windows and dishes to vibrate. Some items might topple from shelves, but bookcases and furniture would remain intact. The larger earthquakes would be felt by everyone in the area. At night, the shaking would awaken many people, especially those living closest to the volcano. Damage to buildings and utilities would be nil in most cases. Sustained episodes of magnitude-4 earthquakes could crack plaster and damage walls in older brick or stone buildings near the volcano.

Tectonic earthquakes occur periodically in south-central and southeast Oregon, and they are capable of exceeding the magnitude of volcanic earthquakes. An example is the Klamath Falls earthquakes, a swarm that began in September 1993 with two large earthquakes of magnitude 5.9 and 6.0 that killed two people and and caused $\$ 7.5$ million in property damage. Aftershocks as large as magnitude 5.1 continued to disturb residents for as much as six months. These earthquakes had no connection with volcanic processes.

Newberry volcano lies at the northwest margin of a broad geographic province known as the Basin and Range, an area whose landforms result from earthquake activity. Tectonic earthquakes as large as magnitude 7 may strike areas south and east of Newberry. Could such tectonic earthquakes trigger eruptions at Newberry? From observations in other earthquake areas, we conclude that 
triggering can only occur if the volcanic system is on the verge of eruption anyway. Statistically speaking, central Oregon residents are far more likely to feel earthquake shaking than to witness an eruption in the area.

\section{VOLCANO HAZARD ZONATION}

Newberry's long, diverse volcanic history has produced an array of hazardous eruptions. The accompanying hazard-zonation map (plate 1) shows areas that could be affected by various future eruptive phenomena. Not discussed in this report are nonvolcanic hazards found in all mountainous regions, such as rockfalls or avalanches. Although we show sharp boundaries for hazard zones, the degree of hazard does not change abruptly at these boundaries but decreases gradually as distance from the volcano increases. Areas immediately beyond hazard zones should not be regarded as hazard free, because the boundaries can only be approximately located. Too many uncertainties exist about the source, size, and mobility of future events to locate zero-hazard zones with confidence.

Three kinds of eruptions are expected to occur at Newberry volcano in the future. The most likely type involves explosive pyroclastic eruptions of rhyolitic magma in small to moderate volumes $\left(0.01-1.0 \mathrm{~km}^{3} ; 13\right.$ million1300 million cubic yards) from vents in the caldera or just beyond the caldera rim. The caldera is the most likely site for such eruptions, owing to the abundance of rhyolite that has erupted there in the past. Also, the presence of lakes and shallow ground water in the caldera increases the likelihood that eruptions from caldera vents will be explosive. Even basaltic magma can generate strong explosions if erupted through water such as the caldera lakes. The next most likely type of future eruption, and one of lesser potential hazard, is a basaltic eruption from vents on the flanks. These would likely produce lava flows and cinder deposits, also of small to moderate volume. The third type, and fortunately the least likely to occur, is a large explosive eruption from a vent in the caldera that discharges several cubic kilometers or more of magma. Such eruptions include those that created the caldera. A description follows of the hazard zones for each of these eruption types as well as other events that might accompany eruptive activity.

\section{Hazard zone for small to moderate, explosive pyroclastic eruptions in or near the caldera}

Hazards expected in this zone are tephra falls, pyroclastic flows and surges, and ballistic projectiles. The caldera has repeatedly been the site of volcanic activity, with rhyolitic eruptive products issuing from seven discrete vents during three eruptive periods in the past 7,500 years. The great likelihood of explosive pyroclastic events, especially in the initial phases of intracaldera eruptions, warrants assigning the greatest degree of hazard to the caldera. On the basis of the distribution of past vents, pyroclastic eruptions may burst forth from vents even as far as $3 \mathrm{~km}(2 \mathrm{mi})$ from the caldera rim, but the probability of rhyolite vents diminishes abruptly beyond the caldera rim. The hazard zone for explosive pyroclastic eruptions includes areas exposed to the threat of pyroclastic flows and surges and thick tephrafall deposits, such as those erupted 1,300 years ago from the vent for the Big Obsidian Flow.

Eruptions that occur within East or Paulina Lakes or along their shores may produce pyroclastic surges that would spread rapidly outward from the vent. The caldera walls would contain much of the devastation created by these eruptions except along the western caldera rim, which is topographically low. Pyroclastic flows or surges erupted in that area could surmount the caldera rim and descend the west flank.

Any pyroclastic eruptions at Newberry would also produce tephra showers. The caldera and upper flanks are most likely to receive substantial accumulations of tephra (10 $\mathrm{cm}$ to several meters, or 4 in. to more than 100 in.), but these sites have few permanent residents. Therefore, risk is minimized by ease of evacuation and sparse development. Downwind sites have more development at risk. 
Mid- to high-altitude winds in central Oregon blow 80 percent of the time toward the northeast, east, and southeast. Millican or Brothers (fig. 1) are the nearest settlements most likely to be downwind during eruptions from caldera vents. However, they lie sufficiently far from the caldera $(30-50 \mathrm{~km}, 20-30 \mathrm{mi})$ that tephra from most eruptions would likely accumulate less than a few centimeters (few inches), but could reach $25 \mathrm{~cm}(1 \mathrm{ft})$ thick during eruptions like those of 1,300 years ago. Similar thicknesses could fall in Bend or La Pine, but suitable wind directions occur infrequently.

On the basis of eruption frequency during the recent geologic past (fig. 2), we estimate the annual probability of explosive eruptions affecting the caldera and immediately adjacent areas is about 1 in 3,000 (four eruptive periods, one basaltic and three rhyolitic, in 12,000 years). The probability of such an eruption occurring in a 30-year period, the duration of many home mortgages or a human generation, is roughly 30 times the annual probability or 1 in 100. We caution that these probabilities are based solely on the long-term behavior of the volcano. Any signs of increased restlessness at Newberry volcano will increase these probabilities dramatically.

\section{Regional tephra hazards}

As a group, other Cascade Range volcanoes possess an equally likely chance to thinly blanket the area with tephra. South Sister and Crater Lake are capable of discharging tephra that could fall on Bend, La Pine, or other towns in the region. Even Mount St. Helens could impact central Oregon. If wind direction had been to the south-southeast on May 18, 1980, Bend would have received 2-4 cm of tephra (1-2 in.) from the eruption of Mount St. Helens despite its location $250 \mathrm{~km}$ distant $(160 \mathrm{mi})$. Such wind conditions occur about five percent of the time.

When all Cascade volcanoes are considered, the annual probability that at least $1 \mathrm{~cm}(0.4 \mathrm{in}$.) of tephra might accumulate in central Oregon ranges from about 1 chance in 1,000 to 1 in 5,000 (fig. 4). Although $1 \mathrm{~cm}$ of ash may seem a trifling accumulation, the recent experience with Mount St. Helens indicates that as little as $0.5 \mathrm{~cm}$ of ash (0.2 in.) is sufficient to bring automobile and truck traffic to a crawl and to close businesses for as much as a week or two.

\section{Hazard zone for lahars or floods on Paulina Creek}

Lahars of greatest concern at Newberry volcano would be those produced in the Paulina Creek drainage on the west side of the volcano, where we show a lahar-hazard zone on plate 1. Small valleys on other flanks, especially on the northeast, could be subject to lahars or floods initiated when pyroclastic flows or surges melt part of a snowpack; forest roads, however, are the only developments at risk in these areas. We don't show a specific lahar-hazard zone in these areas, but effects of lahars and flooding in these areas would be greatest along small valleys in the hazard zone for explosive pyroclastic eruptions and extend downstream into lavaflow hazard zone LA.

The lahar-hazard zone along Paulina Creek encompasses areas that could be inundated by lahars or floods generated by volcanically induced melting of snowpack, by eruptions in Paulina Lake, or by water rapidly displaced when pyroclastic flows enter the lake. We estimate that flows would likely have discharge rates as great as 5,000 cubic meters per second ${ }^{[C]}$. Such a flow would be contained by Paulina Creek canyon, but if the flow were larger, water would spread as a broad sheet flood across the upland surface west of the caldera rim. There it would either infiltrate or be redistributed among many small channels that lead back into Paulina Creek. This upland area of potential flooding is shown stippled on the hazard zonation map (plate 1).

The downstream reach of Paulina Creek is of greater concern, owing to inhabited sites, highway and railroad routes, and major interstate electric transmission lines and natural gas pipelines in the area north of $\mathrm{La}$ Pine. Where Paulina Creek leaves the confines of its canyon, it diminishes in gradient and forms a broad alluvial fan. Lahars could spread across Paulina Prairie and extend north along the flood 


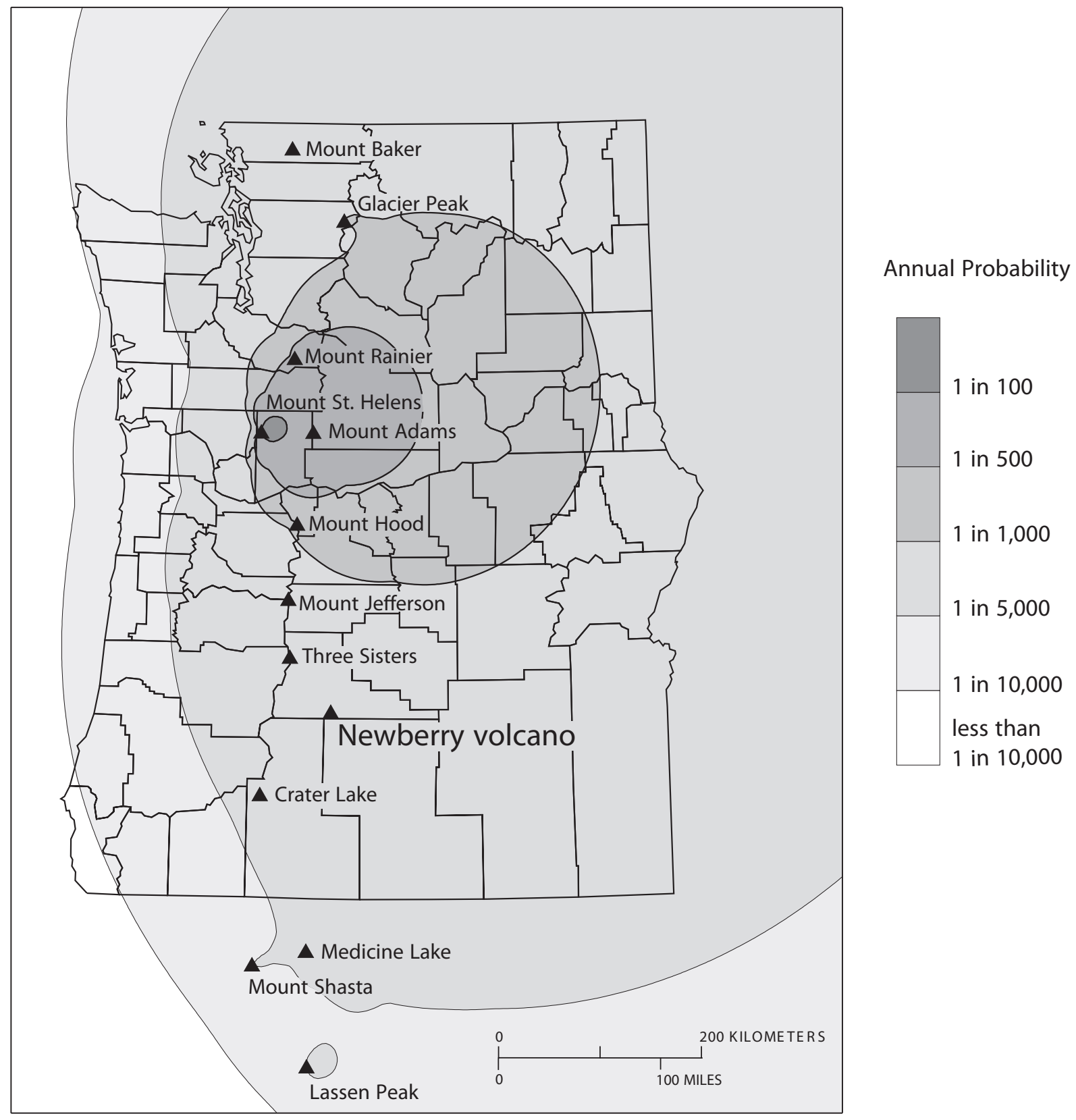

Figure 4. Map showing annual probability of $1 \mathrm{~cm}$ or more of tephra accumulation in Washington, Oregon, and northern California from eruptions throughout the Cascade Range. Probability distribution reflects the frequency of explosive eruptions at each major volcano, the variability in the thickness of tephra that could be deposited at various downwind distances, and the variability in wind direction ${ }^{[\mathrm{E}]}$.

plain of Paulina Creek to its confluence with the Little Deschutes River. Such lahars or floods could bury or destroy U.S. Highway 97 and tracks of the Burlington Northern-Santa Fe Railway Co.

The 100-year flood plain of the Little Deschutes River downstream from Paulina Creek is also included in the hazard zone for lahars and flooding in the event of volcanically induced surges of water from Paulina Lake. The hazard zone ends at the confluence of the Little Deschutes and Deschutes Rivers ${ }^{[D]}$, but effects of flooding could extend some unknown distance dowstream along the channel and flood plain of the Deschutes River. 


\section{Hazard zone for volcanic gases}

Gas presently discharges from hot springs in Paulina and East Lakes and from a gas vent (fumarole) at Lost Lake near the Big Obsidian Flow. Water vapor and carbon dioxide $\left(\mathrm{CO}_{2}\right)$ are major components in the gas. The gas has an odor of rotten eggs (hydrogen sulfide), but its noxious components are currently in very low concentrations.

Gas in the caldera is of little consequence unless the discharge rate were to increase substantially. The hazard zone for gases is restricted to the caldera, owing to the presence of known gas seeps there and the numerous small topographic depressions found upon the caldera floor. Even with increased gas discharge, atmospheric circulation would probably be adequate to disperse the gas and reduce the hazard in most settings. For example, the broad open basins of Paulina and East Lakes are sufficiently well ventilated that accumulation of gases to dangerous levels is unlikely. However, caves and depressions on the young rugged obsidian flows and elsewhere in the caldera are natural sites where accumulation of carbon dioxide and other gases that are denser than air could become lethal. Artificially created enclosures such as manholes, excavations, tents, or snowcaves present the greatest danger of trapping and concentrating gas sufficient to threaten lives.

Some readers may be familiar with rare events in which volcanic lakes trap carbon dioxide in their lower levels for several years and then release the gas catastrophically. In 1986, 1,700 people living near Lake Nyos, Cameroon, were asphyxiated in this manner. Fortunately, such an event is highly improbable at Newberry caldera. Paulina and East Lakes are not deep enough and their water mixes too well during the year to accumulate sufficient carbon dioxide to produce a deadly gas release.

\section{Hazard zones for lava flows of basaltic flank eruptions}

Renewed flank eruptions would produce cinder cones or fissure vents and lava flows. Eruptions would probably include several lava flows, possibly from more than one vent, during a time interval we call an eruptive period. Such periods might range in duration from weeks to a decade. We define two lava-flow hazard zones for Newberry on the basis of likelihood of future lava flows within each zone. Lava-flow hazard zone LA encompasses the area more likely to be the site of flank vents or to be covered by lava, including the caldera. Zone LB includes two main areas: (1) areas on the lower flanks of Newberry that have relatively few flank vents and are chiefly covered by large lava flows from vents farther upslope and (2) lava flows from vents elsewhere in the Cascade Range or Basin and Range. Particular sites that might be affected within each zone cannot be specified in advance. Once precursory activity or a lavaflow eruption begins, scientists can better define areas likely to be affected.

The outer boundary of lava-flow hazard zone LA is determined by encircling the part of the volcano with greatest density of vents as determined by geologic mapping. As shown on the hazard-zonation map, the outline of zone LA broadly defines the elongate shape of Newberry volcano itself, consistent with the idea that the volcano has grown by the repeated eruption of lava from vents preferentially located on the north and south flanks and in the summit region. Indeed, the topographic contour lines may themselves be thought of as probabilistic contours, with likelihood of eruption increasing at higher elevations on the volcano. The caldera, which originated by repeated collapse, is an obvious exception to this concept of linking elevation and eruption probability.

The probability that a flank eruption will affect a given area in zone LA can be estimated only approximately because the frequency of such eruptions prior to the last ones about 7,000 years ago are so poorly known. We infer that the annual probability of a flank eruption occurring in zone LA is roughly 1 in 5,000 to 1 in 10,000. But because lava flows of a flank eruptive period would cover only part of zone LA, the annual probability of a given point in the zone being covered by a lava flow is less than 1 in 10,000 , perhaps substantially less. Within zone LA the probability would be somewhat higher near the caldera and along rift zones and 
somewhat lower at the outer boundary. Again, we caution that these probabilities are based solely on the long-term behavior of the volcano. Any signs of increased restlessness at Newberry volcano will increase these probabilities dramatically.

Another way to estimate a probability is to consider the results from deep drilling midway along the north and south flanks. These holes, located at roughly the 1,700-m elevation $(5,600$ $\mathrm{ft}$ ) on the volcano (see plate 1 ), indicate that lava flows about $600 \mathrm{~m}(2,000 \mathrm{ft})$ in total thickness have been emplaced during the past 600,000 years. From studies at Newberry and other Cascade volcanoes and volcanic fields, we estimate that $10-20 \mathrm{~m}(33-66 \mathrm{ft})$ is a representative range for the average thickness of a field of lava flows that would accumulate during an eruptive period. Therefore, the $600 \mathrm{~m}$ of material in a drillhole would record 30-60 eruptive periods, or an average frequency of burial of that point of once every 10,000-20,000 years at the middle elevations of the volcano. Such frequencies represent annual probabilities ( 1 in 10,000 to 1 in 20,000) that are similar to those estimated above.

Lava-flow hazard zone LB encompasses the entire hazard-map area beyond zone LA. Zone LB includes areas on the lower flanks and downslope from Newberry volcano and elsewhere in the region that have been affected by lava flows less frequently than areas in zone LA. Sources for flows include Newberry volcano or, toward the edges of the map area, other volcanoes in the Cascade Range or central Oregon. We estimate that the annual probability of an eruption in this zone or of lava flows invading the zone from vents in zone LA is roughly 1 in 100,000, or less, on the basis of the frequency of lava-flow coverage in the past one million years and the few, widely scattered vents in the region.

Could eruptions occur in Bend? Could La Pine witness the growth of a small cinder cone? Could lava flows reach the Fort Rock Post Office? The answer to all these questions is yes, but the probability is exceedingly small. Pilot Butte and a handful of other small vents have erupted during the past 500,000 years within what is now the city of Bend. Lava flows that erupted from the flanks of Newberry volcano once progressed across the plain north of Bend, reaching $25 \mathrm{~km}$ (16 mi) beyond Redmond (fig. 1). Geologically, central Oregon is a volcanic terrane, and volcanic activity can be expected in the future. Fortunately for our homes and businesses, eruptions recur infrequently in these more developed areas.

\section{Hazards from large-magnitude explosive eruptions of low probability}

How large an eruption is possible at Newberry volcano? The worst-case scenario is for a large-magnitude explosive eruption or even another caldera-forming eruption, the very process that has occurred at least twice in the past 600,000 years to form Newberry Crater. Such a low frequency of occurrence suggests that the annual probability of another such event is no greater than 1 in 100,000. Another famous example of a caldera-forming eruption created Crater Lake, Oregon, about 100 km (60 mi) southwest of Newberry volcano. A calderaforming eruption would include violent showers of pumice and ash that could continue for days and deposit several meters of tephra on the volcano. Devastating pyroclastic flows could sweep out for $50 \mathrm{~km}$ (30 mi) from the volcano. Today, however, the volcano shows no signs of the volcanic buildup that would precede such a devastating eruption. Although preparing for an event of such small probability is unreasonable, we should nonetheless understand the events that would occur during the maximum credible event.

A question commonly asked is whether Newberry volcano could produce an event similar to the large lateral blast that devastated more than $500 \mathrm{~km}^{2}$ (200 sq. miles) when Mount St. Helens erupted in May 1980. Prior to eruption, a large landslide slipped from the north side of Mount St. Helens after magma had accumulated in the volcano's throat. The effect was to abruptly uncork a pressurized mixture of magma and gas, freeing it to surge across the landscape. At Newberry volcano, such a lateral blast is unlikely. Newberry is broad and gently 
sloping, not a steep-sided cone like Mount St. Helens or other Cascade composite volcanoes. Magma rising into the shallow crust at Newberry volcano would be buttressed by a substantial mass of rock. Small slope failure and associated blasts could conceivably be associated with eruptions near but slightly beyond the caldera walls. The resulting hazards would be confined to the hazard zone for explosive eruptions.

\section{MONITORING AND WARNINGS}

Future eruptions at Newberry volcano will be preceded by premonitory activity. Earthquakes associated with rising magma most likely will give days or weeks of advance warning. Changes in the composition, temperature, or volume of volcanic gases emanating from hot springs and fumaroles might also indicate that an eruption is about to occur. Increased gas discharge could lead to tree kills as observed recently at Mammoth Mountain, California, providing another indication that volcanic gas concentrations were increasing to dangerous levels. When any of these events are recognized, emergencymanagement agencies would be contacted immediately and the level of monitoring would be increased.

Newberry volcano is monitored by the U.S. Geological Survey (USGS). A regional network of seismometers for measuring earthquakes is operated jointly by the USGS and the Geophysics Program at the University of Washington. The USGS conducts periodic leveling surveys across the volcano to assess the volcano's elevation profile. The leveling stations will be remeasured in the event of future earthquake swarms to look for changes that may indicate the volcano is swelling in response to magma injection. Hot-spring gases and caldera lake waters are sampled intermittently. Given Newberry's inactivity, this level of monitoring is appropriate and economical.

At Newberry volcano, much of the area in hazard zones lies within the Deschutes National Forest. The near-absence of people living in the higher-hazard areas on the upper flanks of the volcano simplifies the often complex economic and social aspects of hazard management. Distal parts of the lahar hazard zone on the west flank are already managed as flood plains along Paulina Creek and the Little Deschutes and Deschutes Rivers. Areas subject to lahars that aren't in these flood plains are limited in size but include several subdivisions north of La Pine. People living in these areas at some distance from urban centers need to know about volcano hazards and be prepared to make informed decisions on their own. Planning is prudent because once an emergency begins, public resources may be overwhelmed, and citizens may need to provide for themselves.

\section{SUGGESTIONS FOR FURTHER READING}

\section{Volcano hazards in general}

Blong, R.J., 1984, Volcanic hazards-—a sourcebook on the effects of eruptions: Orlando, Fla., Academic Press, 424 p.

- Probably the most complete reference on volcanic hazards-_including the effects on people, infrastructure, and economic activity. Many examples from specific volcanoes, but not overly technical in its presentation.

Casadevall, T.J. (ed.), 1994, Volcanic ash and aviation safety: Proceedings of the First International Symposium on Volcanic Ash and Aviation Safety: U.S. Geological Survey Bulletin 2047, 450 p.

- Several near-tragic encounters between jet aircraft and ash during the past two decades have led to an improved protocol for avoiding ash or to escape safely whenever an ash plume is encountered accidentally. This report contains numerous articles that explain the effects of ash on aircraft and provide advice to pilots.

Warrick, R.A, and six other authors, 1981, Four communities under ash: after Mount St. Helens: Boulder, Colo., University of Colorado Institute of Behavioral Science Monograph No. 34, 143 p.

- Written in a clear, nontechnical style, this report compares the effects of ash on transportation, public facilities, and businesses in four towns located at increasing distance downwind from Mount St. Helens. The startling conclusion is that even thin ash deposits can cripple a town or city, 
and 0.5 inch or more of ash creates a hazard with impacts lasting for weeks or months. This short book is of special interest to city and county elected officers, city managers, fire and police staff, hospital administrators, or anyone involved in emergency preparedness planning.

\section{Geology and eruptive history of Newberry volcano}

Chitwood, L.A., 1990, Newberry, in Wood, C.A., and Kienle, Jürgen, eds., Volcanoes of North America: United States and Canada, Cambridge, Mass., Cambridge University Press, 354 p.

- A concise summary of Newberry's volcanic history is found on p. 200-202. Available in many libraries or from local booksellers.

Jensen, R.A., 1988, Roadside guide to the geology of Newberry volcano: Bend, Oreg., CenOreGeoPub (20180 Briggs Road, Bend, OR 97701), 75 p.

- A friendly, descriptive road log for geologic field trips around Newberry volcano and into Newberry Crater.

MacLeod, N.S., Sherrod, D.R., Chitwood, L.A., and Jensen, R.A., 1995, Geologic map of Newberry volcano, Deschutes, Klamath, and Lake Counties, Oregon: U.S. Geological Survey Miscellaneous Investigations Map I-2455, scales 1:62,500 and $1: 24,000$.

- A full-color geologic map and pamphlet explaining many aspects of the geology at Newberry volcano. Available from stores locally, from Oregon Department of Geology and Mineral Industries (ph: 503-731-4100), or from USGS Distribution Center (ph: 303-202-4693). The Oregon Geology store may have the best price if ordering fewer than four maps.

\section{ENDNOTES}

[A] The banks of upper Paulina Creek were stripped of Mazama ash and bedrock channels were eroded sometime after about 7,500 years ago (Jensen, R.A., and Chitwood, L.A., 1996, Evidence for recent uplift of caldera floor, Newberry volcano, Oregon [abs.]: Eos [American Geophysical Union Transactions], v. 77, no. 46, p. F792). Cross sectional areas of the flood channel, determined by finding the height above creek floor at which Mazama ash is preserved, range from 90 to $230 \mathrm{sq}$. meters (1,000-2,500 sq. ft) (L.A. Chitwood, written commun., 1996). The flow volume and velocity we use in our worst-case flooding analysis [endnote B] requires cross sectional area of 500 sq. meters.

[B] Few published examples are available for volcanoes that have displaced water from their summit lakes during eruptions. A large eruption involving much nonmagmatic debris at Ruapehu Volcano, New Zealand, in 1975 ejected about 23 percent of the water from that lake (roughly 1.6 million cubic meters $\left(\mathrm{m}^{3}\right)$ of water and lake-floor sediment) in a few hours (Nairn, I.A., Wood, C.P., and Hewson, C.A.Y., 1979, Phreatic eruptions of Ruapehu: April 1975: New Zealand Journal of Geology and Geophysics, v. 22, no. 2, p. 155-173.). Most of the water was thought to be ejected during surges, and most washed back into the lake following each explosion. The eruptions were not observed because they occurred at night, but they produced floods with maximum estimated discharges as great as $5,000 \mathrm{~m}^{3}$ per second at gaging stations 5-6 km (3-4 mi) downstream in several drainages. Average flow velocities of the floodwater ranged from about $5.5 \mathrm{~m}$ per second to 12 $\mathrm{m}$ per second (11 to $27 \mathrm{mi}$ per hour), with higher values close to the volcano in those drainages having higher discharges.

The explosions took place during a heavy rainstorm with strong winds. It was surmised that the winds directed a disproportionate amount of water into those drainages where higher discharges were recorded. The snow pack on the volcano was low, so snowmelt contributed little to the flooding.

The Ruapehu lake is only $500 \mathrm{~m}$ in diameter, compared to Paulina Lake's 1,300-m diameter (1,640 ft compared to 4,260 ft diameter). Paulina Lake's larger size might pose a larger hazard, but its larger volume and greater depth would absorb substantially more of the energy released during the explosion, perhaps actually reducing the amount of water expelled.

[C] Maximum discharge on the upper part of Paulina Creek would probably be on the order of a few thousand cubic meters per second, using the Ruapehu example described in note B. To calculate inundation levels on Paulina Creek, a discharge throughout the channel of $\sim 5000 \mathrm{~m}^{3}$ per second $(180,000 \mathrm{cfs})$ and an average velocity of $10 \mathrm{~m}$ per second was assumed (on basis of measurements at Ruapehu).

A flow of $5,000 \mathrm{~m}^{3}$ per second with a velocity of $10 \mathrm{~m}$ per second would raise the stream level such that the inundated cross-sectional area equals 
$500 \mathrm{~m}^{2}$. Using 1:24,000-scale topographic maps, the level of inundation required for the flow to occupy $500 \mathrm{~m}^{2}$ was calculated at stream profiles every $400 \mathrm{~m}$ or so down Paulina Creek from Paulina Lake to Paulina Prairie. The inundation remains entirely within the Paulina Creek canyon.

Discharge could either decrease, remain constant, or increase with distance downstream, depending on whether this flood represented a brief surge from the lake, whether it was prolonged, whether it bulked up to a debris flow along the stream course, or whether a snowpack was present in the overflow area. Presuming that discharge remains near-constant downstream as far as Paulina Prairie, then the flood behaves roughly as a steadystate water flood or an impulsive lahar.

For readers interested in comparing these flow rates with the maximum discharge resulting solely from weather-related flooding on central Oregon streams and rivers, we recommend the following reference: Moffatt, R.L., Wellman, R.E., and Gordon, J.M., 1990, Statistical summaries of streamflow data in Oregon: Volume 1-Monthly and annual streamflow, and flow-duration values: U.S. Geological Survey Open-File Report 90-118, 413 p. Some of this data for the Deschutes River basin may be accessed electronically on the World Wide Web using the following Uniform Resource Locator:

http://wwworegon.wr.usgs.gov/data_dir/ mans_dir/actv94.html\#HDR12

[D] From Paulina Prairie downstream to the Little Deschutes River, the stream valley is too broad to determine inundation levels without far more precise contouring of the ground surface than the 20$\mathrm{ft}$ contour interval shown on published maps. Also, modeling the flow in the absence of confining valley walls is problematic. Consequently, the lahar hazard-zone boundaries have their greatest subjectivity along this stretch of stream. Downstream from Paulina Prairie, the hazard zone is drawn to encompass the flood plain.

From Paulina Prairie downstream, discharge would decrease for lahars, owing to deposition of entrained material. For impulsive floods, discharge would also decrease downstream as the peak flood height attenuates with distance.

[E] Tephra hazard zones generated by computer program developed by R.P. Hoblitt (U.S. Geological Survey, Cascades Volcano Observatory, written commun., 1996).

[F] We are indebted to Norm MacLeod (U.S. Geological Survey, ret.) and Larry Chitwood (U.S. Forest Service, Deschutes National Forest), whose reviews of the manuscript both improved its final presentation and sharpened our thinking about the probability and extent of hazard zones. David Leslie (Deschutes County Community Development Department) provided advice and maps for flood plains and downstream flooding hazards. Bob Jensen (Deschutes National Forest) has continued to probe and describe the geologic mysteries of Newberry volcano, some of which have a bearing on our interpretation of hazards. 